\title{
Electronic Visualisation and the Arts (EVA 2014)
}

\author{
London, UK \\ 8 - 10 July 2014
}

Editors

Dr. Kia Ng

Prof. Jonathan P. Bowen

Dr. Sarah McDaid 


\section{Abstract}

The Electronic Visualisation and the Arts London 2014 conference (EVA London 2014) is co-sponsored by the Computer Arts Society (CAS) and British Computer Society (BCS) - the Chartered Institute for IT, of which the CAS is a specialist group. 2014 marks the 25th Anniversary of EVA London. Over the last two decades, the EVA conference has established itself as one of London's most innovative and interdisciplinary conferences in the field of digital visualisation. The papers in this volume touch on music, performance, electronic art, imaging technology, medical visualisation, museums and their collections, virtual communities, landscape visualisation, augmented reality, 3D imaging, interfaces, and enhanced reality, as well as other areas. The latest research by established scholars, early career researchers, practitioners, and students can be found here.

For more information about EVA 2014, visit www.eva-london.org or search on Twitter for EVALondonConf. 


\section{Full Synopsis}

2014 marks the 25th Anniversary of EVA London! Over the last two decades, the EVA London conference on Electronic Visualisation and the Arts has established itself as one of the United Kingdom's most innovative and interdisciplinary conferences. It brings together a wide range of research domains to celebrate a diverse range of interests with a specialised focus on visualisation.

The EVA London 2014 conference presents a wide spectrum of papers, presentations, demonstrations, a research workshop and a special pre-conference event: "V\&A Digital Futures meets EVA London". It is a forum where the sciences, arts, humanities, and performance, are equally at home. EVA London 2014 presents 76 papers and abstracts from 24 countries, by researchers inside and outside academia, from graduate artists, PhD students, seasoned industry professionals, established scholars, and senior researchers, who value EVA London for its interdisciplinary community. This year, the conference features three keynote speakers: Prof. Sally-Jane Norman from the Attenborough Centre for the Creative Arts, University of Sussex; Dr Lizzie Jackson from Ravensbourne; and Tom Wickham-Jones from Wolfram Research.

The proceedings has resulted from a highly selective peer review process, fitting as many excellent submissions as possible into the limited timetable of the conference. The papers in this volume touch on music, performance, electronic art, imaging technology, medical visualisation, museums and their collections, virtual communities, landscape visualisation, augmented reality, 3D imaging, interfaces, and enhanced reality, as well as other interdisciplinary areas.

EVA London is part of a larger network of EVA international conferences. In the past twenty years, EVA events have been held in Athens, Beijing, Berlin, Brussels, California, Cambridge (both UK and USA), Dallas, Delhi, Edinburgh, Florence, Gifu (Japan), Glasgow, Harvard, Jerusalem, Kiev, Laval, London, Madrid, Montreal, Moscow, New York, Paris, Prague, Thessaloniki, and Warsaw. Further venues for EVA conferences are very much encouraged by the EVA community. 


\section{Editors}

This conference was edited by:

Dr. Kia Ng, PhD, FBCS, FRSA, FloD, CEng, CSci, is Director of the Interdisciplinary Centre for Scientific Research in Music (ICSRiM) at the University of Leeds. Kia is involved in several research domains including gestural interfaces, interactive multimedia, computer vision, document imaging and computer music, in collaboration with many European and international organisations and individuals in the field. Large-scale projects include i-Maestro on technology-enhanced learning (coordinator), CASPAR on digital preservation and AXMEDIS on cross-media with over 20M Euro research funding. Kia has over 200 publications and presented keynotes and invited lectures in over 33 countries. www.kcng.org

Prof. Jonathan P. Bowen, MA Oxon, FBCS, FRSA, is Professor of Computer Science at Birmingham City University, Chair of Museophile Limited, a museum and IT consultancy company that he founded in 2002, and Emeritus Professor of Computing at London South Bank University. In recent years, he has been a visiting professor at East China Normal University (Shanghai, China), the Pratt Institute (New York, USA) where he taught a masters course on museum informatics, the University of Waikato (New Zealand), the University of Westminster, and King's College London. Previously he has held posts at the University of Reading, the Oxford University Computing Laboratory and Imperial College, London. He contributes to Wikipedia on cultural and computing-related topics. www.jpbowen.com

Dr. Sarah McDaid, PhD, MBCS, is a freelance Usability Consultant and Sessional Lecturer at London South Bank University. She has taught at a variety of educational establishments both in the UK and Europe. Her teaching areas include systems analysis and design, business programming, humancomputer interaction, usability, interactive multimedia and, personal and professional development. As a consultant she has worked for a number of museums and art centres including the British Museum and the Nerve Centre, Northern Ireland. Her research interests include interactive television, mobile usability and human-computer interaction in a social context. www.linkedin.com/in/sarahmcdaid 


\section{Papers:}

\section{Seeing music and performance}

Alexander Deweppe, Nuno Diniz, Pieter Coussement and Marc Leman Engaging Audiences through a Participatory Design Approach with the Interactive Music Installation 'SoundField' http://dx.doi.org/10.14236/ewic/EVA2014.1

Anna Shvets and Charles de Paiva Santana Modelling Arvo Pärt's Music with OpenMusic http://dx.doi.org/10.14236/ewic/EVA2014.2

Kia Ng, Joanne Armitage and Alex McLean The Colour of Music: Real-time Music Visualisation with Synaesthetic Sound-colour Mapping http://dx.doi.org/10.14236/ewic/EVA2014.3

\section{Keynote}

Sally Jane Norman Live Engagement with Data http://dx.doi.org/10.14236/ewic/EVA2014.4

\section{Electronic art}

João dos Santos Moving Drawings. A Digital Mediation for the Linear Drawing Metaphor: the Line as the Trace Left by a Moving Point (Rawson) http://dx.doi.org/10.14236/ewic/EVA2014.5

Iris Asaf The Poetic and the Thoughtful: The Creative Poiesis of Algorithmic Art and Design http://dx.doi.org/10.14236/ewic/EVA2014.6

Michael Lesk and Annamarie Klose Summarising Pictures http://dx.doi.org/10.14236/ewic/EVA2014.7

Eunice Goncalves Duarte $\quad X$ Stories of a Technology Breakdown: How Digital Tools Influence Aesthetic and Artistic Options http://dx.doi.org/10.14236/ewic/EVA2014.8 


\section{Imaging technology for culture}

David Lyons and David R. FlatlaEye For An Eye http://dx.doi.org/10.14236/ewic/EVA2014.9

Francesca Uccheddu, Anna Pelagotti, Vito Cappellini and Emanuela Massa 3D Technologies for Measurement of Painting Surface Deformations: A Case Study

http://dx.doi.org/10.14236/ewic/EVA2014.10

Clare Brennan and Lynn Parker Animating Dance and Dancing with Animation: A Retrospective of Forever Falling Nowhere $\quad$ http://dx.doi.org/10.14236/ewic/EVA2014.11

\section{Demonstration}

Lee Wagstaff Transforming Photographs into Sculptures

http://dx.doi.org/10.14236/ewic/EVA2014.12

\section{Visualising the body}

Xin Tong, Diane Gromala, Chris Shaw and Patrick Clarke

Transformation between Electronic Arts and Chronic Pain: Long-term Body Activity Data Visualisation and Pain Animation Expression http://dx.doi.org/10.14236/ewic/EVA2014.13

Jiann Hughes BB got your Beat: Visualising Heartbeats within a Biosensing Artwork http://dx.doi.org/10.14236/ewic/EVA2014.14

Angela Chang, Selene Mota and Henry Lieberman GestureNet: A Common Sense Approach to Physical Activity Similarity $\quad$ http://dx.doi.org/10.14236/ewic/EVA2014.15

\section{Demonstration}

Licia Calvi, Hans Bouwknegt, Moniek Hover, Frank Ouwens, Juriaan van Waalwijk and Albert van Schendel Experiencing Van Gogh's Heritage: A Case Study

http://dx.doi.org/10.14236/ewic/EVA2014.16

Laura Carletti, Dominic Price, Gabriella Giannachi, Rebecca Sinker, Derek McAuley and John Stack 
Art Maps - Putting the Tate Collection on the Map

http://dx.doi.org/10.14236/ewic/EVA2014.17

\section{Research workshop}

Elena Gaevskaya and Tayanan Laska Ways of Access to Virtual Cultural Heritage http://dx.doi.org/10.14236/ewic/EVA2014.18

Elke Reinhuber Counterfactuals in Media Arts http://dx.doi.org/10.14236/ewic/EVA2014.19

Lorna Moore In[bodi]mental: Body Swapping - A Choreography of Shared Selves using Real-time Video http://dx.doi.org/10.14236/ewic/EVA2014.20

Beth Woodward Alvarez and Ramon Palau Secondary School String Orchestra Students
The Performance Effects of Online Video Tutorials on http://dx.doi.org/10.14236/ewic/EVA2014.21

Rehan Zia Tonemapping Multi-shot Digital Photographs of Real World Environments http://dx.doi.org/10.14236/ewic/EVA2014.22

Hannah L. Jacobs Visualising the New Woman http://dx.doi.org/10.14236/ewic/EVA2014.23

Beatrice Bretherton and Roger Watt Music and Motion http://dx.doi.org/10.14236/ewic/EVA2014.24

James Rosindell Big Data Visualisation with Fractal Geometry http://dx.doi.org/10.14236/ewic/EVA2014.25

Anna Nazarova How can Typography be Represented in an Alter-modernity Context? http://dx.doi.org/10.14236/ewic/EVA2014.26

Clare Plumley Brain in Pain: Body Mapping, Pain Visualisation and Mapping the Invisible http://dx.doi.org/10.14236/ewic/EVA2014.27

Leonie Dunlop Beasts and Bodies: Visualising the Landscape through Place-names http://dx.doi.org/10.14236/ewic/EVA2014.28

Dion Rezki Socio-digital-visualisations as Positive-reinforcement Mechanisms for Encouraging Prosocial and Constructive Behaviours http://dx.doi.org/10.14236/ewic/EVA2014.29

\section{Museums and collections}


Suzanne KeeneMuseums and the Digital: The View from the Micro Gallery http://dx.doi.org/10.14236/ewic/EVA2014.30

Alison Taubman Cybraphon: Collecting the Physical or the Digital at National Museums Scotland? http://dx.doi.org/10.14236/ewic/EVA2014.31

Derek J. Smith Trench Gothic: The Computer Visualisation of a Disturbing Great War Artwork http://dx.doi.org/10.14236/ewic/EVA2014.32

\section{Keynote}

Lizzie Jackson 'Findability': A Central Issue for Quality Media in a Networked World http://dx.doi.org/10.14236/ewic/EVA2014.33

\section{Communities and the digital}

Camille C. Baker ICT\&ART Connect: Connecting ICT \& Art Communities - Early Outcomes http://dx.doi.org/10.14236/ewic/EVA2014.34

Angela Chang, Lidet Tilahun and Cynthia Breazeal Visualisations of Data from the Literacy Tablet Reading Project in Rural Ethiopia $\quad$ http://dx.doi.org/10.14236/ewic/EVA2014.35

Moshe Caine, Eyal Tagar and Idit Ben Or Unfolding Communities: Imaging the Past, Envisioning the Future http://dx.doi.org/10.14236/ewic/EVA2014.36

Joanna Moll Surveillance through Social Networks along the US-Mexico Board http://dx.doi.org/10.14236/ewic/EVA2014.37

\section{Workshop}

Lampros Stergioulas, Munir Abbasi and Carl Smith Technology Futures for the Creative Industries:

Presenting the Cr-eAM Roadmaps http://dx.doi.org/10.14236/ewic/EVA2014.38

\section{Visualising landscapes}


Kieran Baxter Grounding the Aerial: The Observer's View in Digital Visualisation for Built Heritage http://dx.doi.org/10.14236/ewic/EVA2014.39

Daniel Buzzo Time Travel: Time Dilation $\quad$ http://dx.doi.org/10.14236/ewic/EVA2014.40

Stuart Dunn Crowd-Sourced Cartography to Visualise the Forgotten: Mapping Britain's Corpse Roads http://dx.doi.org/10.14236/ewic/EVA2014.41

Tessa Morrison and Mark Rubin Using Visualisation to Test Historical Utopian Cities on a Modern Audience http://dx.doi.org/10.14236/ewic/EVA2014.42

\title{
Demonstration
}

\author{
Cameron Beckfield and J C Diaz Tulsa's Art Deco Cross-Platform Mobile Tour App
} http://dx.doi.org/10.14236/ewic/EVA2014.43

Amy Robinson The Zandra Rhodes Digital Study Collection Project at the University for the Creative Arts http://dx.doi.org/10.14236/ewic/EVA2014.44

\section{Demonstration}

Jonathan Weinel, Stuart Cunningham, Nathan Roberts, Shaun Roberts and Darryl Griffiths EEG as a Controller for Psychedelic Visual Music in an Immersive Dome Environment http://dx.doi.org/10.14236/ewic/EVA2014.45

Toby Gifford, Simon Linke and Leah Barclay Listening to the Thames http://dx.doi.org/10.14236/ewic/EVA2014.46

\section{Imaging, music and performance}

Lindsay MacDonald, Ali H. Ahmadabadian, Stuart Robson and lan Gibb High Art Revisited: A Photogrammetric Approach http://dx.doi.org/10.14236/ewic/EVA2014.47

Helena Bisby, Adam Cooper, Stephen James, Alec Robertson and Kia Ng A Tactile Audio Visual Instrument using Sound Source Localisation http://dx.doi.org/10.14236/ewic/EVA2014.48

Damian Keller, Nuno Otero, Victor Lazzarini, Marcelo Soares Pimenta, Maria Helena de Lima, Marcelo Johann and Leandro Costalonga Relational Properties in Interaction Aesthetics: The Ubiquitous 
Music Turn $\quad$ http://dx.doi.org/10.14236/ewic/EVA2014.49

Kia Ng, Alex McLean and Alan Marsden Big Data Optical Music Recognition with Multi Images and Multi Recognisers http://dx.doi.org/10.14236/ewic/EVA2014.50

\section{Demonstration}

Chiara Passa The Widget Art Gallery http://dx.doi.org/10.14236/ewic/EVA2014.51

Frederico Visi, Duncan Williams, Eduardo Miranda and Giovanni Dothel An Immersive Media Model of Amyotrophic Lateral Sclerosis http://dx.doi.org/10.14236/ewic/EVA2014.52

Terry Trickett Visual Music $\underline{\text { http://dx.doi.org/10.14236/ewic/EVA2014.53 }}$

\section{Workshop}

Leigh Garrett, Robin Burgess, Amy Robinson and Anne SpaldingExploring Research Data Management in the Visual Arts http://dx.doi.org/10.14236/ewic/EVA2014.54

\section{EVA London birthday panel}

James R. Hemsley Twenty Five Years Ago: Still Looking at the Future http://dx.doi.org/10.14236/ewic/EVA2014.55

\section{Augmented reality}

Kevin Whiteside, Gentry Atkinson, Mary Mikel Stump, Dan Tamir and Grayson Lawrence Musing: Adaptable Mobile Augmented Reality Application for Museums and Art Galleries http://dx.doi.org/10.14236/ewic/EVA2014.56

Roma Patel and Deborah Tuck Narrative Approaches to Design Multi-screen Augmented Reality Experiences http://dx.doi.org/10.14236/ewic/EVA2014.57

Carl H. Smith Context Engineering Hybrid Spaces for Perceptual Augmentation 
http://dx.doi.org/10.14236/ewic/EVA2014.58

\section{Keynote}

Tom Wickham-Jones Exploring the Beauty of Mathematics with Mathematica

http://dx.doi.org/10.14236/ewic/EVA2014.59

\section{D imaging}

Jeni Maleshkova and Matthew Purver Beyond the White Cube: Presentation of Visual Art in Interactive 3D Environments http://dx.doi.org/10.14236/ewic/EVA2014.60

Hartmut Schwandt and Joachim Weinhold $\quad 3 D$ Technologies for Museums in Berlin http://dx.doi.org/10.14236/ewic/EVA2014.61

Bernd Breuckmann 25 Years of High Definition 3D Scanning: History, Start of the Art, outlook http://dx.doi.org/10.14236/ewic/EVA2014.62

Martin Doerr, Ioannis Chrysakis, Anastasia Axaridou, Maria Theodoridou, Christos Georgis and Emmanuel Maravelakis A Framework for Maintaining Provenance Information of Cultural Heritage 3Dmodels http://dx.doi.org/10.14236/ewic/EVA2014.63

\section{Demonstration}

Renick Bell Data Visualisation Tools for Enhancing Live Coding Usability and Audience Experience http://dx.doi.org/10.14236/ewic/EVA2014.64

David BouchardData Materiality http://dx.doi.org/10.14236/ewic/EVA2014.65

Kristina Mettus and Anna Nazarova Fundamental Research in Cosmoparticle Physics and the Visualisation: Symbiosis or graphics and conceptualisation http://dx.doi.org/10.14236/ewic/EVA2014.66

Jeremy C. Creasey Creating Pictures in Quick Response Codes http://dx.doi.org/10.14236/ewic/EVA2014.67 


\section{Workshop}

Franco Niccolucci and Paola Ronzino Learning Opportunities for Sharing Data in the ARIADNE Project http://dx.doi.org/10.14236/ewic/EVA2014.68

\section{Interfaces}

Oliver Gingrich, Evgenia Emets and Alain Renaud Transmission - Sonifying, Visualising and

Analysing Neural Activity through Telepresence http://dx.doi.org/10.14236/ewic/EVA2014.69

Calliope Georousi Innovating iTV Browsing: Designing an Affective Search Engine http://dx.doi.org/10.14236/ewic/EVA2014.70

Murat Germen The Unstoppable Rise of Mobile Imaging and Aesthetics

http://dx.doi.org/10.14236/ewic/EVA2014.71

Ajay Kumar Tiwari Visualisation Strategies in Abstract Animation http://dx.doi.org/10.14236/ewic/EVA2014.72

\section{Demonstration}

Andre Murnieks Connecting with Users through Interactive Prototyping: Understanding User Behaviour through Building the Black Box and its Electronic Innards

http://dx.doi.org/10.14236/ewic/EVA2014.73

Gretchen Andrus Andrew Wearable Technology and Electronic Visualisation of Artistic Process: Google Glass meets Fine Art Painting http://dx.doi.org/10.14236/ewic/EVA2014.74

\section{Digital enhanced reality}

Rikke Schmidt Kjærgaard and Ebbe Sloth Andersen Seeing Streptococcus pneumoniae, a Common Killer Bacteria http://dx.doi.org/10.14236/ewic/EVA2014.75

Jonathan P. Bowen and Tula Giannini Digitalism: The New Realism? 
http://dx.doi.org/10.14236/ewic/EVA2014.76 